McKee-Farrar prosthesis (Cole, 1971). Yet few cases of fat embolism have been reported after total hip replacement for degenerative joint disease with femoral head prostheses embedded into acrylic cement after reaming the marrow. This is in contrast with the episodes after inserting Thompson's prosthesis in concurrent patients with subcapital fractures (Dandy, 1971; Gresham et al., 1971). This has been related to the younger and usually fitter subjects on whom total-hip replacement surgery is carried out, compared with the less fit and older subjects who sustain subcapital fractures. There is evidence that death from fat embolism selects out the elderly (Sevitt, 1962) and this is supported by the high mean ages of the present fatal ( 85 years) and non-fatal cases ( 82 years). This same may be true for patients exposed to the combined risk of marrow reaming and raised marrow pressure.

The statistical help and other useful comments from Professor Sir Richard Doll, F.R.S., and Dr. Richard Peto are gratefully acknowledged.

\section{References}

Burgess, D. M. (1970). British Medical fournal, 3, 588. Charnley, J., Murphy, J. C. M., and Pitkeathly, D. A. (1971). British
Medical fournal, 3, 474.

Cole, P. V. (1971). Report to the Working Party on Acrylic Cement in Orthopaedic Surgery, Department of Health and Social Security. In press.

Danckardt-Lillieström, G., Lorenzi, G. L., and Ollerud, S. (1970). Acta Orthopaedica Scandinavica, Suppl. No. 134.

Dandy, D. M. (1971). British fournal of Accident Surgery, 3, 85.

Frost, P. M. (1970). British Medical fournal, 3, 524.

Gresham, G. A., and Kuczỳnski, A. (1970). British Medical fournal, 3, 465. Gresham, G. A., Kuczynski, A., and Rosborough, D. (1971). British Medical fournal, 2, 617.

Harris, N. H. (1970). British Medical fournal, 3, 523.

Hume, M., Sevitt, S., and Thomas, D. P. (1970). Venous Thrombosis and Pulmonary Embolism. London, Oxford University Press.
.

Ohnsorge, J. (1971). Fournal of Bone and foint Surgery, 53B, 758.

Phillips, H., Cole, P. V., and Lettin, A. W. F. (1971). British Medical fournal, 3, 460 .

Powell, J. N., McGrath, P. J., Lahiri, S. K., and Hill, P. (1970). British Medical fournal, 3,326 .

Sevitt, S. (1962). Fat Embolism. London, Butterworth.

Sevitt, S. (1968). Proceedings of the Royal Society of Medicine, 61, 143.

Whitenack, S. H., and Hausberger, F. X. (1971). American fournal of Pathology, 65, 335.

Young, J. S., and Griffith, H. D. (1950). Fournal of Pathology and Bacterio$\log y, 62,293$.

\title{
Phlegm and Filters
}

\section{J. RIMINGTON}

British Medical fournal, 1972, 2, 262-264

\section{Summary}

Male mass radiography volunteers aged 40 or more were questioned about their sputum production and cigarette consumption in relation to type (filter or plain) smoked. Of 10,414 volunteers, 3,045 smoked filter cigarettes and 2,393 smoked plain cigarettes. The rate of persistent daily sputum of filter smokers (31.9\%) was significantly lower than that of plain cigarette smokers (37.2\%). A similar pattern was maintained when age and cigarette consumption were standardized. These figures are thought to understate the less injurious nature of filter cigarettes, since more than half of the filter smokers with persistent sputum developed this while previously smoking plain cigarettes.

Whatever the reasons for the less injurious nature of filter cigarettes, it seems that cigarette smokers unable to stop smoking might suffer less from chronic bronchitis if they changed to filter cigarettes.

\section{Introduction}

During the past 15 years there has been a pronounced swing from plain to filter cigarette smoking, and the proportion of cigarette tobacco used in this form has risen from $2.7 \%$ in 1956 to $66 \%$ in 1968 (Todd, 1969). During this time there has been speculation about the protective value, if any, of filter tips in relation to diseases associated with tobacco smoking. Two studies of this problem, investigations into the risk of lung cancer in smokers who switch to filters (Bross and Gibson, 1968; Wynder et al., 1970), suggest that there is some protection as regards lung cancer. The investigations were retrospective in type, and

St. Thomas' Hospital, Stockport

J. RIMINGTON, M.D., Medical Director, Mass Radiography Service, Southern Division, Manchester Regional Hospital Board it was in order to lay the foundations for a prospective study of the same matter that much of the information used in this paper was collected, the object being to relate the type of cigarette smoked to lung cancer incidence over a period of years. The collection of the data, however, also gave an opportunity to determine the prevalence of persistent sputum among the cigarette smokers of the sample.

With information on sputum production to hand it has been possible to relate it to the type of cigarette smoked, and the results are reported in this paper. The definition of persistent sputum for the purposes of this study is the production of phlegm from the chest during the last two years, either on most days of the year or on most days for at least three months of the year.

\section{Material and Methods}

The data were obtained during 1970 and 1971 by questioning men, from industry and the general public, who volunteered for mass radiography examination and who were aged at least 40 .

After recording the age, address, and other identification details of each volunteer, a smoking history was taken which included the type (filter or plain), the amount, the manner, and the duration of cigarette smoking. A cigarette smoker was defined as one who had smoked at least one cigarette daily for as long as a year, and those who had stopped smoking at least two weeks before attending the radiography unit were classed as ex-smokers. Hand-rolled cigarette smokers were counted as plain or filter smokers according to whether or not filter-tips were inserted, and the amount of tobacco used was converted to cigarette equivalents $(1 \mathrm{oz}(28 \mathrm{~g})$ a week $=4$ cigarettes a day). Mixed smokers (those smoking as much as 1 cigar a week or $1 \mathrm{oz}(28 \mathrm{~g})$ of pipe tobacco a month in addition to their cigarettes) were excluded from the investigation.

Each volunteer was asked if he brought up or coughed up phlegm from his chest, and, if so, whether or not he did this on most days of the year or on most days for at least three months of the year and for how many years he had done this. Chest - $x$-ray films on $100 \mathrm{~mm}$ film were taken and any significantly 
abnormal cases were referred for further investigation or treatment. All volunteers with incomplete or invalid records were excluded $(2 \cdot 4 \%)$, as were 68 persons who had persistent sputum but whose $x$-ray films showed disease or abnormality (other than changes sometimes seen in chronic bronchitis) which was considered likely to be the cause of the sputum-for example, certain tuberculous disease, lung cancer, bronchiectasis, etc.

Most of the volunteers considered here lived or worked in towns within the South-east Lancashire conurbation.

\section{Smoking Habits}

The smoking habits of the volunteers are compared in Table I with those of a nationwide sample taken in 1968 (Todd, 1969). The figures given under the headings "U.K." relate to the nationwide sample and are recalculations of the original figures after exclusion of the mixed smokers. Moreover, the handrolled cigarette smokers of the nationwide sample $(5 \%)$ have been added to the plain cigarette smoking group because only $7 \cdot 5 \%$ of these habitually inserted filter tips into their cigarettes (Tobacco Research Council, 1971).

TABLE I-Smoking Habits of 10,414 Male Mass Radiography Volunteers Aged 40 Years or more Compared with Those of a Nationwide Sample (U.K.) Taken in 1968

\begin{tabular}{|c|c|c|c|c|c|c|}
\hline \multirow{2}{*}{$\begin{array}{l}\text { Age Group } \\
\text { in Years }\end{array}$} & \multicolumn{2}{|c|}{$\begin{array}{c}\text { Non-smokers, } \\
\text { Ex-smokers, } \\
\text { Non-cigarette Smokers }\end{array}$} & \multicolumn{2}{|c|}{$\begin{array}{l}\text { Filter } \\
\text { Cigarette } \\
\text { Smokers }\end{array}$} & \multicolumn{2}{|c|}{$\begin{array}{l}\text { Plain } \\
\text { Cigarette } \\
\text { Smokers } \\
\end{array}$} \\
\hline & $\underset{(\%)}{\text { M.M.R. }}$ & U.K. & $\underset{(\%)}{\text { M.M.R. }}$ & $\underset{(\%)}{\text { U.K. }}$ & $\underset{(\%)}{\text { M.M.R. }}$ & $\begin{array}{l}\text { U.K. } \\
(\%)\end{array}$ \\
\hline $\begin{array}{l}40-59^{*} \\
60 \text { or more }\end{array}$ & $\begin{array}{l}46.0 \\
53.5 \\
\end{array}$ & $\begin{array}{r}45.5 \\
54.5 \\
\end{array}$ & $\begin{array}{l}31 \cdot 0 \\
24 \cdot 0 \\
\end{array}$ & $\begin{array}{l}28 \cdot 5 \\
19 \cdot 0 \\
\end{array}$ & $\begin{array}{l}23 \cdot 0 \\
22 \cdot 5 \\
\end{array}$ & $\begin{array}{l}26 \cdot 0 \\
26 \cdot 5 \\
\end{array}$ \\
\hline
\end{tabular}

* U.K. sample 35 to 59 years.

As will be seen in Table I, the volunteers' smoking habits are almost identical with those of the nationwide sample as regards the composite group of non-smokers, ex-smokers, and noncigarette smokers. However, while the total percentage of cigarette smokers is almost identical in the two samples, the proportion of filter to plain smokers is higher among the volunteers. This is almost certainly due to the fact that the smoking habits of the nationwide sample were taken two years before those of the volunteers, and during these two years the swing from plain to filter smoking has continued. In fact, it is likely that the smoking habits of the volunteers are almost identical with those of the general male population in comparable age groups when allowance is made for the $22 \%$ increase in filter cigarette sales and the $16 \%$ decrease in plain cigarette sales which occurred from 1968 to 1970 (Tobacco Research Council, 1971).

\section{Persistent Sputum Prevalence}

The sample was first examined for the percentage rates of persistent sputum in five-year age groups, and it was obvious that the rates rose with increasing age, irrespective of smoking habits and tobacco consumption. Because of this, age-standardized percentage rates of persistent sputum have been calculated by basing them on a population equally divided in five-year age groups. These are given in Table II as well as the actual rates.
The percentage rate of persistent sputum is lower in the composite group of non-smokers, ex-smokers, and non-cigarette smokers but is higher in both filter and plain cigarette smokers, rising with increased consumption. More particularly, the actual percentage of persistent sputum is lower in the filter smokers than in the plain cigarette smokers and this difference is maintained irrespective of the amount smoked. Statistical tests show that the differences are significant in the moderate, the high, and the total consumption categories. The differences in the percentage of persistent sputum between the filter and plain cigarette smokers are maintained in the age-adjusted figures which follow the same pattern as the actual figures.

It is known that about $90 \%$ of cigarette smokers in the age groups considered here began smoking cigarettes before the age of 25 (Todd, 1969), and because the consumption of filter cigarettes was infinitesimal before 1956 it follows that almost all the filter cigarette smokers among the volunteers started their cigarette smoking with plain cigarettes. Consequently, the earlier smoking habits of the filter smokers may have contributed to the development of their persistent sputum. An analysis of the duration of the sputum shows this to be so, because 572 of the filter smokers with persistent sputum developed their symptom after starting cigarette smoking in general but before starting filter smoking in particular. The Chart shows the age-standardized percentage rates of persistent sputum for each consumption category and type of cigarette smoked and also the percentage of filter smokers whose persistent sputum developed while previously smoking plain cigarettes.

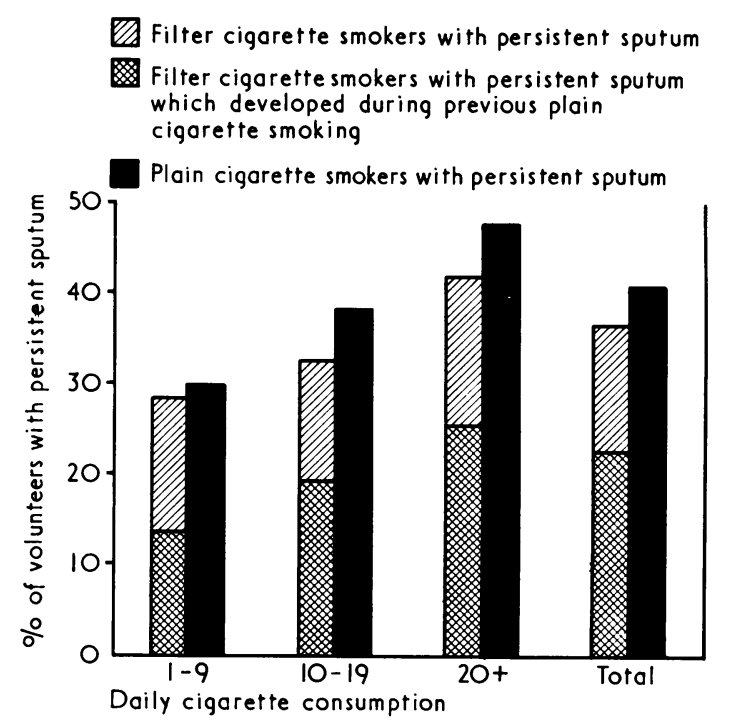

Age-standardized percentages of persistent sputum among the cigarette smokers in 10,414 male volunteers for mass radiography aged 40 or more, shown in consumption categories.

\section{Discussion}

It is possible that those who switch to filters are more health conscious and possibly healthier than those who do not switch. Although this possibility cannot be excluded, two reasons make it seem unlikely. Firstly, most filter smokers give cheapness, convenience, and enjoyment as their reasons for smoking filter

TABLE II-Number and Percentage of Persons with Persistent Sputum among 10,414 Male Volunteers Aged 40 or more Analysed by Smoking Habit and Type of Cigarette Smoked (P. = Plain Cigarette Smokers. F. = Filter Cigarette Smokers)

\begin{tabular}{|c|c|c|c|c|c|c|c|c|c|c|}
\hline & \multirow{3}{*}{$\begin{array}{c}\text { Non-smokers, } \\
\text { Ex-smokers, } \\
\text { Non-cigarette } \\
\text { Smokers }\end{array}$} & \multicolumn{8}{|c|}{ Cigarette Smokers } & \multirow{3}{*}{$\begin{array}{c}\text { All } \\
\text { Subjects }\end{array}$} \\
\hline & & \multicolumn{2}{|c|}{$1-9$} & \multicolumn{2}{|c|}{$10-19$} & \multicolumn{2}{|c|}{$20+$} & \multicolumn{2}{|c|}{ Total } & \\
\hline & & F. & P. & F. & $\mathbf{P}$. & F. & P. & F. & P. & \\
\hline $\begin{array}{lll}\begin{array}{l}\text { No. of volunteers } \ldots \\
\text { No. with persistent sputum }\end{array} & \ldots & \ldots \\
\text { Percentage with persistent sputum } & \ldots\end{array}$ & $\begin{array}{c}4,976 \\
836 \\
16 \cdot 8\end{array}$ & $\begin{array}{l}382 \\
97 \\
25 \cdot 3\end{array}$ & $\begin{array}{c}259 \\
75 \\
28 \cdot 9\end{array}$ & $\begin{array}{c}1,095 \\
304 \\
27 \cdot 7 \\
0 \cdot 001<\end{array}$ & $\begin{array}{c}878 \\
304 \\
34.6 \\
P<0.01\end{array}$ & $\begin{array}{l}1,568 \\
571 \\
36 \cdot 4 \\
0.01<P\end{array}$ & $\begin{array}{c}1,256 \\
513 \\
40 \cdot 8 \\
<0 \cdot 02\end{array}$ & $\begin{array}{l}3,045 \\
972 \\
31 \cdot 9 \\
\mathbf{P}<\end{array}$ & $\begin{array}{c}2,393 \\
892 \\
37 \cdot 2 \\
0 \cdot 001^{3}\end{array}$ & $\begin{array}{r}10,414 \\
2,700 \\
25.9\end{array}$ \\
\hline Age-standardized percentage with sputum & $19 \cdot 7$ & $28 \cdot 2$ & $29 \cdot 8$ & $32 \cdot 5$ & $37 \cdot 9$ & $41 \cdot 6$ & $47 \cdot 2$ & $36 \cdot 4$ & 40.9 & $28 \cdot 9$ \\
\hline
\end{tabular}


cigarettes, and, secondly, there was no noticeable alteration in the rate of switching to filters after the first report of the Royal College of Physicians in 1962 (Royal College of Physicians, 1971).

The sample was restricted to volunteers from industry and from the general public, and although highly selected groups of symptomatic cases such as doctors' referrals were excluded, the rates of persistent sputum are high. They are, in fact, higher than those found in an earlier sample of mass radiography volunteers taken in 1964 and 1965 (Rimington, 1969), but a greater proportion of the volunteers considered here came from more densely populated and industrialized districts in the Manchester area than was the case in the earlier sample. Even though the rates of persistent sputum are high, they are still comparable with those found in other investigations of similar symptoms among cigarette smokers of comparable age groups (Higgins, 1959; Reid et al., 1964; Lowe, 1969).

The social class of the volunteers was not recorded routinely because the investigation was not set up specifically for the study of persistent sputum prevalence. Nevertheless, because the proportions of the two types of cigarette smokers might vary in the social classes and because it is well known that there is a rise in chronic bronchitic symptoms with decline in social class, it was thought advisable to obtain an assessment of the social class distribution of the two types of cigarette smokers. A $10 \%$ sample of the occupational records of the cigarette smokers was taken and the social class determined (General Register Office, 1960). In filter smokers the percentages in three social class groups (I and II, III, and IV and V) were 15,64 , and 21 , respectively, whereas corresponding percentages in plain cigarette smokers were 10 , 63, and 27. When these distributions are taken in conjunction with the type of gradient of bronchitic symptoms with decline in social class found in other studies (College of General Practitioners, 1961; Rimington, 1969), it seems unlikely that the association of lower social classes with preference for plain cigarette smoking could account for the findings of this study.

If it is accepted that the factors discussed here have not significantly influenced the findings, then it must be agreed that filter cigarette smoking does lead to lower rates of persistent sputum than plain cigarette smoking. The mechanisms involved could be threefold. Firstly, the actual removal of part of the irritant substances in cigarette smoke by the filter-there seems little doubt that irritant substances, either in the particulate or the gas phase, or both, of cigarette smoke do cause lung damage (Thurlbeck et al., 1963) and this damage seems likely to result in excessive sputum. Secondly, the presence of the filter leads to a reduction in the actual amount of tobacco available for smoking compared with plain cigarettes of comparable size. Thirdly, the filter renders impossible the practice of smoking to a short butt, and it is known that the last puffs that reduce a moderate butt to a short butt contain considerably more tar than earlier puffs (Moore and Bock, 1968).

\section{Conclusions}

This study has shown moderately lower rates of persistent sputum in filter cigarette smokers as compared with plain cigarette smokers. The differences are consistent, statistically significant, and are maintained irrespective of age and tobacco consumption. Although it is unlikely to have had a significant effect, the tendency of plain cigarette smokers to be of a lower social class than filter cigarette smokers could have slightly raised the rate of persistent sputum in the former group. It is, however, almost certain that if most of the filter cigarette smokers had not previously smoked plain cigarettes their rate of persistent sputum would have been substantially lower.

While there is no doubt that smokers of any type of cigarette are liable to develop chronic bronchitic symptoms such as persistent phlegm, it seems likely that those plain cigarette smokers who are unable to stop smoking cigarettes would suffer less if they smoked filter brands of comparable size.

I wish to thank all those who helped during the investigation: Professor M. R. Alderson, formerly director of the Regional Cancer Registration Bureau, advised in the planning of the study; the Manchester Regional Hospital Board kindly allowed the staff of the Mass Radiography Service, Southern Division, to obtain and record the volunteers' sputum and smoking details, and allowed the staff of the computer section of the Board's headquarters to process the information-I am particularly grateful for the care and attention to detail given by the staffs of these departments.

\section{References}

Bross, I. D. J., and Gibson, R. (1968). American fournal of Public Health and the Nation's Health, 58, 1396.

College of General Practitioners (1961). British Medical fournal, 2, 973.

General Register Office (1960). Classification of Occupations, 1960. London, H.M.S.O.

Higgins, I. T. T. (1959). British Medical fournal, 1, 325

Lowe, C. R. (1969). British Medical fournal, 1, 463 .

Moore, G. E., and Bock, F. G. (1968). National Cancer Institute Monograph, No. 28 , p. 89 .

Reid, D. D., Anderson, D. O., Ferris, B. G., and Fletcher, C. M. (1964) British Medical fournal, 2, 1487.

Rimington, J. (1969). British fournal of Diseases of the Chest, 63, 193.

Royal College of Physicians (1971). Smoking and Health Now. London, Pitman.

Thurlbeck, W. M., Angus, G. E., and Pare, J. A. P. (1963). British fournal of Diseases of the Chest, 57,73 .

Tobacco Research Council (1971). Personal communication from D. H Beese, Secretary, Tobacco Research Council.

Todd, G. F. (editor) (1969). Statistics of Smoking in the United Kingdom. Research Paper 1. 5th edn. London, Tobacco Research Council.

Wynder, E. L., Mabuchi, K., and Beattie, E. J. (1970). Fournal of the American Medical Association, 213, 2221. 